\title{
Productivity and Staff Development in Corporate Organisations.
}

\author{
Don- Baridam Letam \\ Department of management Faculty of Management sciences Rivers State University of Science and \\ Technology.
}

\begin{abstract}
No organization can survive without the effective utilization of people to achieve both the objectives of the enterprise and the satisfaction and development of the employees.

Today, organizations are growing into large, complex operations whose structure are continually changing and therefore require that many employees be prepared for new assignments.

Studies have identified the quality of manpower in any organization, as one of the critical factors affecting its survival and productivity. Organizations cannot survive without having competent and experienced employees, who are living to tackle the challenges of a changing world. Investment in manpower development is justified when management is able to get a good return on its investment.

It is for the above reasons that this paper attempts to discuss productivity and staff development in corporate organizations: A cost benefit analysis.

Keywords: Corporate organization, cost benefit analysis, productivity, staff development.
\end{abstract}

\section{Introduction.}

Employee development has become increasingly vital to the success of modern organizations because rapid changes in technology require that employees possess the knowledge and skills necessary to cope with the new processes being introduced (Broadhurst, $2012^{[1] ;}$ Dukakis, 2002 $2^{[2]) .}$

The growth of organizations into large, complex operations whose structures are continually changing also requires that many employees be prepared for new assignments.

There is a silent crisis between people and corporate organizations in Nigeria. The survival of our society therefore, depends on how well we acknowledge and understand this crisis. Organizations are the frameworks through which most society's work is carried out and within which individual seek to satisfy most of their needs organizations. As instruments for meeting societal and individual needs, must be sensitive to changes in expectations and demands from both quarters. Changes in our society particularly in the values of the work force calls for the development of new methods that will be able to deal with the situation.

Indeed, the changing values of the work force, coupled with the rapid rate of changes in the technological environment throws a challenge not only to the human resources managers in Nigerian corporate organizations, who must design human resources management system to meet the needs of the time, but also to the supervisors who must cope with these challenges in order to supervise their subordinates effectively.

To increase productivity, organization requires more initiatives, innovation and dedication. These can only be achieved when the organization is able to develop its employees to the required level of competence.

According to Ohabunwa (1999 ${ }^{[3 .]}$ if organizations develop its employees, managers and superiors would have the confidence to delegate authority to their subordinates but when subordinates are not properly developed, it would be difficult for authority to be delegated to them by their superiors.

The structures, functions and powers of any organization, no matter how well designed, defined and assigned, can become operational and efficacious only if there are adequate/competent employees and increased productivity.

Studies (Sorge and Warner, 1981) ${ }^{[4 .]}$ have identified the quality of manpower in any organization as one of the critical factors affecting its survival. No organization can survive without having employees who are efficient and capable of tackling challenges of a changing world. Investment in staff development is justified when management is able to get a good return on its investment.

This paper attempts to discuss productivity and staff development in Corporate Organizations: A cost benefit analysis. To achieve this objective, the paper is organized under the following sub-headings:

1) The concept of staff development

2) Cost/benefit analysis of staff development

3) The optimization of the staff development system for improved productivity 


\section{The Concept Of Staff Development}

According to Dutta $\left(2005^{5[5 .]}\right.$ staff development refers to the processes, programs and activities through which every organization develops, enhances and improves the skills, competencies and overall performance of its employees and workers.

Every organization, as soon as it gets to any size (perhaps 1,000 people) begins to feel a need to systematize its management of manpower. Perhaps the pay scales have got out of line with apparently similar level jobs paying very different amounts; perhaps there is a feeling that there are a lot of neglected skills in the organization that other departments could utilize if they were aware they existed; perhaps individuals complained that they do not know where they stand or where their future is; whatever the historical origin, some kind of central organization is formed to put some system into order.

Staff development fosters initiative and creativity of employees and helps to prevent manpower obsolescence, facilitates the recognition and aggregation of different kinds of human inputs (Romer, $1992^{[6]}$; Arnoff $1971^{\text {) }}$ [7.].

The human inputs into an organization or system are skills and capabilities embodied in individuals or the work force, which, in part, are acquired, through improved through health and nutrition, and education and training.

The importance of staff development cannot be therefore be over emphasized. Although ideas are the critical inputs in the production of more valuable human and non- human capital, human capital is the most important input in the production of new ideas. While we agree that physical capital(such as computer) is sometimes used in ancillary way, a trained person is still the central input in the process of trial and error, experimentation, guessing, hypothesis formulation, and articulation that ultimately generates a valuable new idea that can be communicated to and used by others.

The concept of staff development as earlier stated to the issue of profitability, productivity, growth and marginal returns as differences in productivity among workers may reflect different level of skills acquired through investment in staff development. This therefore, means that management policy on staff development will no doubt create a very weak link between staff development and productivity improvement.

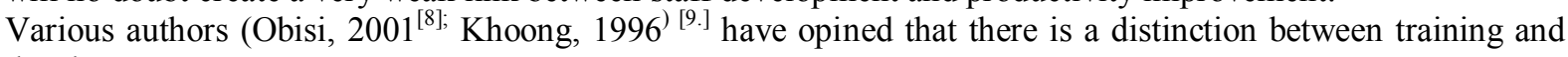
development.

Training is imparting the knowledge and skills required to perform a task or accomplish an objective; development is a broader concept that deals with attitudes and habits. Training is job oriented; development is man oriented. Training is temporary in duration; development is a continuous process.

Training is concerned with performance of a specific, present job; development is concerned with the future growth of the individual performing that job.

As such, training is one aspect of the broader concept of development. Development deals with the whole man and employs behavioral concepts to guide the person toward actualization of his capabilities.

The ultimate aim of every training and development program is to add value to human resource. Any training and development program that would not add value should be abandoned. Organizations should therefore make training and development of their employees a continuous activity.

Having discussed the concept of staff development, the next section would discuss the costs and benefits of staff development.

\section{Cost/Benefit Analysis Of Staff Development.}

There is much the organization can and must do to develop executives. According to Armstrong (2010) [10.]The organization has a serious moral obligation to develop its most important resource, people. The need to train and develop employees is not simply a demand of social responsibility; it is a demand of sound business practice.

There will be a shortage of qualified managers for years to come and there will be more people to manage, a knowledge explosion that antiquates university or college education before a man becomes a manager, and a type of young executive who will make his prime commitment to his self development rather to an organization. This employee will be less motivated by money and will look for challenges and opportunities for education and self development in selecting an organization. If a company is to attract, develop, and hold this type of employee- and it must in order to survive- it has to concern itself with continuing education and development of personnel.

Organizations can no longer look to the university to carry the full responsibility for formal education, particularly now that the education standard in Nigeria is falling. A phenomenon thoughtful businessmen perceive today is what may be termed a "Knowledge- experience gap". This is the gap that exists between the new-hire who is a recent university or M.B.A graduate and his Manager.

This grad's knowledge is current, but lacks experiences; the manager is experienced but his knowledge is not current. Frustrations are built into this relationship for both manager and the new- hire. Managing this people 
presents its own problems. The disturbing aspect of this gap is that it is self- perpetuating- by the time the grad gains experience and subsequently becomes a manager, his knowledge is no longer current. He will experience the same gap with his new- hires, but from the other side. And the wheel turns again, since there is no such thing as instant experience, this gap can be closed by making the manager's knowledge current. This can be accomplished at least partially, by the company's training and development programme.

Many practical benefits accrue to the organization that engages in executive training programmes. These include; increased productivity as qualifications are enhanced, less waste, less machine maintenance, fewer accidents, less labor turnover and increased employees job satisfaction- since training can improve the employees' self esteem, more confidence in management, etc.

While we agree that the benefits of staff development far outweigh its costs, it is reasonable to say also that there are costs which if not well managed can adversely affect productivity. These costs include; losing an employee after he has been trained to competing or other firm or organizations, layoff as a result of unfavorable economic climate, death, underutilization of the trained employee, the cost of training development programme.

Kaufan $(1974)^{[11 .]}$ asserted that management can minimized these costs and maximize its benefits through an effective implementation of manpower development strategy. Hence, the next section would discuss how this can be achieved.

\section{The Development Of Manpower.}

Our contention in this section is that three major variables affect the development and maintenance of the desired manpower development system.

According to Gilbert $\left(1978^{[12]}\right.$ these variables are information, instrumentation, and motivation. These variables can be translated into data, instruments and incentives respectively at the environment support level. The tactics with which management develops its manpower will preserve it or destroy it.

The main objective of establishing a manpower development system is to create a human system that will live on while achieving the aims of the organization Hence, there is need for systematic effort to prevent such a system from destruction and obsolescence.

According to Baridam $\left(2002^{[13] \mathrm{t}}\right.$ here are two types of manpower development objectives. The first type is organization and employee effectiveness. The second has to do with the improvement of productivity, labor cost and ensuring compliance. These objectives must influence employee job performance, absenteeism, attitude and employee staffing requirements (the number of employees in the right jobs).

The survival of an organization depends on the achievement of the two types of manpower development objectives mentioned above, which in turn depends on the effort to develop manpower.

Attention must be given to a manpower development strategy that will create an environment in which there will be individual organization and corporate effectiveness. The strategy is presented in the manpower Development Model in Table 1.

\begin{tabular}{|c|c|c|c|}
\hline Information & & Instrumentation & Motivation. \\
\hline $\begin{array}{l}\text { Environmental } \\
\text { support }\end{array}$ & 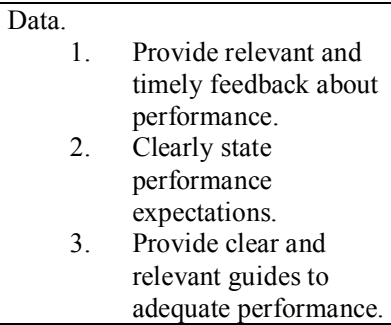 & $\begin{array}{l}\text { 1. Consider human } \\
\text { factor in the } \\
\text { design of tools } \\
\text { and materials. }\end{array}$ & $\begin{aligned} & \text { Incentives. } \\
& \text { 1. } \begin{array}{l}\text { Provide financial } \\
\text { incentives to good } \\
\text { performers. }\end{array} \\
& \text { 2. } \begin{array}{l}\text { Provide social or Non- } \\
\text { monetary incentives }\end{array} \\
& \text { 3. } \begin{array}{l}\text { Provide development } \\
\text { opportunities. }\end{array}\end{aligned}$ \\
\hline $\begin{array}{l}\text { Person's repertoire } \\
\text { of behavior }\end{array}$ & $\begin{aligned} \text { Knowledge } \\
\text { 1. } \\
\begin{array}{l}\text { Determine training } \\
\text { needs for exemplary } \\
\text { performance }\end{array} \\
\text { 2. } \begin{array}{l}\text { Scientifically design } \\
\text { training to match the }\end{array} \\
\text { needs } \\
\text { 3. } \begin{array}{l}\text { Provide suitable } \\
\text { placement. }\end{array}\end{aligned}$ & $\begin{array}{l}\text { Capacity } \\
\text { 1. Select people } \\
\text { with mental and } \\
\text { physical ability } \\
\text { to perform as } \\
\text { well as the } \\
\text { exemplary. }\end{array}$ & $\begin{aligned} \text { Motives } & \\
\text { 1. } & \text { Assess motives for } \\
\text { working. } & \text { Recruit people to } \\
& \text { match the realities of } \\
& \text { the situation. }\end{aligned}$ \\
\hline
\end{tabular}

ADAPTED AND MODIFIED FROM THOMAS GILBERT IN HUMAN COMPETENCE, 1978, p. 88.

At any given time the management strategy may be improved by improvements in environmental support variables (data, instruments and incentives) or improvement in the employee's knowledge, capacity for exemplary performance or motives or any combination of actions contained in the six celled model.

However, the set of actions to be taken will depend on the area of greatest need for manpower development. Management actions have been affected on information flow, tools and materials for work, capacity and incentives. A carefully planned tactics and policies can be used to affect employee training. 


\subsection{Actions of manpower development.}

Although there seems to be a constant war (Sabotage, lack of patriotism) against a state of 100 percent optimization of manpower, management needs to watch out for any anti optimization behavior tactics or policy within the organization.

Small investment in manpower development yields great dividends in productivity/improvement. The cost of taking optimization actions cannot be compared with the consequences of destroying the manpower development system. Hence eight distinct actions are discussed below-

\subsubsection{Provision of data:}

The importance of providing relevant and frequent feedback cannot be over emphasized. Gilbert (1978) ${ }^{[12]}$ suggested that feedback helps the employee to know the behavior to maintain and behavior to change. It is also pro-optimization for management to clearly state or describe what is expected of the employee.

\subsection{Actions on knowledge and skills.}

Kaufman $\left(1974^{[11]}\right.$ stated that obsolescence can occur when employees do not keep up with changing techniques of doing their job effectively, or the jobs may no longer be needed and employees fail to adjust to the needs of the available job. Hence, manpower development requires that employees are up to date in their knowledge and skills. Training should be done as a strategy to achieve the organization goals and as a responsibility to employees. The best way for individuals to make themselves "inflation proof" is to maintain their own wealth producing capacity, that is, their skill and knowledge. This therefore, means that human capacity can be prevented from deteriorating by developing the knowledge and skills of individuals within the human resource system (Baridam, 2002)[13]

We should stress that manpower development efforts directed at improving knowledge and skills should:

1. Analyze the training needs in the different framework of organization, the operations and the individual.

The organization need analysis should reveal the needs, which, if met, will ensure a steady supply of critical skills and management.

2. Scientifically design training to match the needs determined in (1)

3. Place the trained individuals in jobs suitable for their training. The individuals should be transferred to other jobs where their expertise can be utilized.

\subsection{Actions related to instrumentation.}

The consideration of human beings is very important in the design of the manmade objects, facilities and environments that people use in the various aspects of life. The objectives of human factors in the design of man-made objects, facilities and environments are to enhance the functional effectiveness with which people can use them and to maintain or enhance human health, safety and satisfaction. The instruments to be used for work must therefore not threaten the health, safety and satisfaction of the users.

\subsubsection{Physical and mental capacity.}

Baridam $\left(2002^{[13]}\right.$ asserted that employees assigned to tasks they have intrinsic difficulties in performing usually develop low morale and a sense of failure. On the other hand, employees who are assigned to tasks far below their ability feel bored and underutilized.

Another aspect of job assignment is job overloading which could be referred to as giving an employee too much within certain time and resource constraints. Such job assignment practices leads to anti- development of manpower.

Hence, management should therefore schedule jobs for times when people are at their best physical and mental state.

\subsubsection{Material and social incentives.}

The development of manpower can be induced using materials and social incentives. These incentives and disincentives include financial rewards and costs, increases and decreases in comfort and convenience, social approval and disapproval, commitments to corporate and share with others.

Manpower development may be optimized or destroyed/neglected, depending on the procedure employed in the use of materials and social incentives. Optimization may result from:

- Providing greater financial incentives for good performers and financial costs to poor performers

- Increasing the comfort of exemplary performers while the convenience of poor performers should be decreased. This set of actions may take the form of promotion/demotion of transfer/shift change.

- Giving social approval to good performers and disapproval to poor performers. Social approval may be in the form of awards of medals, certificates and designation as employee-of-the month. 
- Allowing good performers the privilege of participating in certain programmes, while poor performers are denied membership of such programmes.

The value of the incentives above must be desirable to the employees' in order to enhance productivity. Executives of manpower development should pursue optimization actions along the line of the various incentives and disincentives above. The motives are not incongruous with the aims of management.

\subsubsection{Manpower development through job posting.}

Job posting is an excellent way of managing the manpower development (Mahon and Yeager, 1976)[14]. Through job posting, organizations are able to attract people with the right aspirations and career plans. However, job posting tend to exclude the chance of attracting outside candidates with superior knowledge, skills and attitudes into the organization. This is because individuals motivated to apply for vacancies on their own produce an excellent organizational climate for individual organizational optimization.

Management should reduce outside interference with its manpower development plan by using job posting especially on key positions in organization. Such practice will reduce training and development costs.

\subsubsection{Manpower development replacement chart.}

A careful audit of the manpower development system can reveal deficiencies in the system and bring to focus potentials for improvement. Such improvement may involve replacing some "dead woods " that hinder the management improving productivity. The current ineffective employees may be replaced with trained individuals' in order to protect the system from destruction and neglect.

Employee replacement organization charts should be prepared annually to give a quick overall indication of the levels with the "back ups" (those who are being prepared to take over from incumbents on some specified future date)

The incumbents and those to replace them are identified through a careful audit of the human resource system. The audit focuses on the abilities of the individuals within the system.

\section{Conclusion}

We have in this paper discussed the models manpower development strategy that will create an environment in which there will be individual organization and corporate effectiveness. This model represents new thrust for management, which implies new demands in the year ahead. Organizations must manage better practices, systems and values must adapt to changing conditions. Human resource management represents the cutting edge of any organizational practices in managing a costly and valuable resource- people. Organizations must learn to create a human system that will live on while achieving the aims of the organization. All systems and practices that bear on performance must therefore be planned to synchronize as a total system; job evaluation, job definition, compensation, appraisal, selection, training and development but a few. Effective manpower development will, therefore, not result from simple gimmick solutions, but only from broad carefully orchestrated management approaches.

\section{References.}

[1]. J. Broadhaust, "Employment development is a great business opportunity: investment in people is the key to company growth," human resource management international digest, vol.20, no 6, pp27-30, Jan 2012.

[2]. I.P. Doukakis, "The role of employment development in customer relations: the case of UK retail banks," corporate communications: An International Journal, Vol.7. No.1. pp.62-76. May 2002.

[3]. S. Ohabunwa, "Nigeria Business Environment in the New Millennium," presented at HRD UNILAG, Lagos. June 27-28. 1999.

[4]. A.Sorge and M.Warmer, "Comparing work organizations and Manpower Training cross-culturally," international journal of manpower, vol.2. iss.3, pp 2-5. July 1981.

[5]. P. Dutta, 'what is the definition of staff development," Ehow contributing water, 2005, pp.62-76

[6]. P.M. Romer, "Two Strategies for Economic development using ideas and producing ideas." Proceedings of the World Bank Ansheal Conference on development economics.

[7]. J. Arnoff, “ Achievement motivations training and executives advancement" journal of Applied Science. New York, vol.7. no 1. Pp 35-57. May 1971.

[8]. C. Obisi, "Employee development, issues and dimensions, Unical Journal of Public Administrator, Vol. 1, pp.34-39, Sept. 2001.

[9]. C.M. Khoong, "An integrated system framework and analysis methodology for manpower planning," international journal of manpower, vol.17, no.1, pp.26-46, may.1996

[10]. M. Armstrong, A handbook on human resource management practice, $10^{\text {th }}$ ed. London and Philadelphia, Kogan page, 2010. Pp.4450 .

[11]. H. Kaufman, “Obsolescence and professional career development,” New York: Amacon, 1997,ch 3.

[12]. T. Gilbert, "Human competence," in publication of the international society for performance improvement 1978, p.88.

[13]. D.M Baridam, "Manpower development as a factor in revenue generation," presented at the national seminar on new strategies for revenue mobilization at state and local levels organization, ECOWAS Secretariat, Abuja, Aug 14-15, 2002.

[14]. J. McMahon and W. Yeager, "Manpower and career planning," in Caring R. Training and Development handbook. New York: McGraw-Hill Inc, 1976. 